\title{
BIOMASSZA PLAZMAGÁZOSÍTÁSÁNAK ENERGETIKAI KÖLTSÉG-HASZON ELEMZÉSE
}

\author{
Bodnár István \\ intézeti tanszékvezetö adjunktus, Miskolci Egyetem, Fizikai és Elektrotechnikai Intézet, \\ Elektrotechnikai és Elektronikai Intézeti Tanszék \\ 3515 Miskolc, Miskolc-Egyetemváros, e-mail:vegybod@uni-miskolc.hu
}

\begin{abstract}
Absztrakt
A tanulmány egy plazmatechnológiával végzett, biomassza energetikai célú hasznositásának energetikai költség-haszon elemzését mutatja be. Az energetikai költség-haszon elemzésem nem klasszikus pénzügyi elemzés. Az energetikai költség-haszon elemzés lényege, hogy a plazmagázositásnál az alternativ segédgáz fajlagos energia kihozatalra gyakorolt hatását, valamint a bevétel növekedést és annak bekerülési költségét vizsgáljuk. Amennyiben egy segédgáznál az energetikai és a pénzügyi haszon magasabb, mint az energetikai, vagy pénzügyi költség, akkor az a segédgáz előnyösen alkalmazható.
\end{abstract}

Kulcsszavak: biomassza, plazmagázositás, szén-dioxid, költség-haszon elemzés

\begin{abstract}
The study presents a cost-benefit analysis of plasma technology for biomass energy purposes. My energy cost-benefit analysis is not a classic financial analysis. The main point of energy cost-benefit analysis, that we look at the effect of alternative auxiliary gas on specific energy output in plasma gasification and look at revenue growth and its extra cost. If an auxiliary gas has higher energy and financial benefits than the energy or financial costs, then that auxiliary gas is preferably applicable.
\end{abstract}

Keywords: biomass, plasma gasification, carbon-dioxide, cost-benefit analysis

\section{Bevezetés}

A plazmatechnológia 1973-as megjelenése óta első sorban a veszélyes ipari, valamint a klór tartalmú hulladékok ártalmatlanítására alkalmazzák. A plazma nagy hőmérsékletü ionizált gáz, amely lehetővé teszi a környezetre veszélyes anyagok és vegyületek teljes lebontását. Napjainkban egyre nagyobb ütemben terjed alkalmazása föleg az Amerikai Egyesült Âllamokban és egyes ázsiai országokban. A kisebb hőmérsékletü plazmatechnológiát, vagy plazmagázosítást hatékonyan alkalmazzák települési szilárd hulladék, valamint biomassza környezetbarát energetikai hasznosítására is. Ezen technológiák nagy előnye, hogy a hulladékól, illetve biomasszából éghető szintézisgázt állítanak elö, amely ez által hatékonyabban hasznosítható gázmotorokban és gázturbinákban. Mind emellett gyorsan (néhány tíz per alatt) indítható erőmủvek is üzemeltethetők, ellentétben a hagyományos égetést alkalmazó több órás, vagy napos indítási idővel rendelkező víz-gőz körfolyamatú erőmüvekkel. Az ilyen erőmüvek szabályozása is gyorsabb, rugalmasabb, mert a plazmafáklyákkal és a segédgázok mennyiségével, illetve típusával a folyamat gyorsítható, vagy lassítható. Amennyiben nem áll rendelkezésre megfelelő mennyiségü települési szilárd hulladék, vagy biomassza, akkor lignit, vagy barnaszén hasznosítására is 
alkalmasak. A plazmareaktorok igen nagy napi feldolgozókapacitással is építhetők, így akár többszáz MW teljesítményű erőművi blokkok kiszolgálására is alkalmasak.

Jelen kutatómunka során fás szárú biomassza plazmagázosítással történő energetikai célú hasznosítását vizsgáltam energetikai költség-haszon elemzés módszerével az alkalmazott szén-dioxid gázosító közeg mennyiségi változásának függvényében.

\section{A plazma-gázosítás}

A plazmatechnológia müködésének megértéséhez elsőként célszerü definiálni a plazma fogalmát. A plazma ionizált gáz, ami inert gázáramban nagy áramerősségü elektromos ív hatására alakul ki az elektródok között. A folyamat során a katódból kilépő töltött állapotú elektronok gerjesztik az ívtérben elhelyezkedő atomokat, részecskéket. A gerjesztés fényjelenséget okoz, amit villamos ívnek nevezünk. A nagy átfolyó áramok miatt az ívtérben a kialakuló nagy hőmérséklet hatására, az anyagok plazma állapotba kerülnek, ami a negyedik halmazállapotnak tekinthető [1].

Plazmatechnológiák esetén a maghömérséklet rendszerint $3.000-5.000{ }^{\circ} \mathrm{C}$ közötti, de akár 30.000 ${ }^{\circ} \mathrm{C}$ is elérhető lenne [1]. Müszaki megközelítésből már az $5.000{ }^{\circ} \mathrm{C}$ hőmérséklet is jelentős problémát jelent, mert költséges müszaki kerámiák és fémötvözetek alkalmazását teszi szükségessé [2]. Ilyen hőmérsékleten a hulladékok összetevői, mint például a toxikus anyagok, alkotóelemeikre bomlanak. $5.000{ }^{\circ} \mathrm{C}$ felett a vegyi anyagok és a mérgező gázok (dioxinok és a furánok) teljesen lebomlanak. Környezetet károsító anyagok csak kis mennyiségben, vagy egyáltalán nem képződnek [3]. Ugyan bevett kereskedelmi technológiának számít, azonban az eljárás rendkívül összetett, drága és képzett üzemeltető közremüködését igényli $[4,5]$.

Az 1. ábra egy plazmareaktor elvi felépítését és müködését szemlélteti az anyagáramokon keresztül. A reaktor felső kiáramlású és ellenáramú müködést biztosít. Megfigyelhető, hogy a reaktor három jól elhatárolható térrészre osztható, és lefelé szükölő kialakítású. A felső térrész a szintézisgáz-gyüjtő rész, amely térfogata a reaktor térfogatának mintegy kétharmadát teszi ki. A középső rész a hulladéktér, amely fogadja a feladott hulladékot és a felszálló szintézisgáz felhasználásával előmelegíti. A segédgáz bevezető csonkjai is itt helyezkednek el. A segédgáz előmelegítéséről a szintézisgáz hütéséből származó hő gondoskodik. A harmadik térrész az olvadt salak gyüjtésére szolgál. A plazmafáklya a salakgyüjtő rész felső részén helyezkedik el. A reaktor belső felületei hőálló kerámiaszigeteléssel vannak ellátva [6].

A reaktor méretei és arányai a méretnövelésnél, a nagyobb kapacitásra történő tervezésénél játszik fontos szerepet. Két eltérő feldolgozó képességü reaktor akkor nevezhető geometriailag, valamint áramlás- és hőtechnikai szempontból is hasonlónak, ha bennük a hőmérséklet-eloszlás és az áramlási jelleg azonos képet mutat. Ekkor biztosítható, hogy ugyanaz a folyamat játszódik le bennük. Mivel a plazmafáklyákat teljesítménykategóriákba sorolják, ezért a méretnövelés során az üzemi nyomás lesz a változó paraméter. Így elóállhat, hogy két ugyan olyan geometriai méretekkel (térfogattal) rendelkező reaktor eltérö kapacitással rendelkezik. A nagyobb nyomáson üzemelő reaktor nagyobb feldolgozó képességgel bír. Az üzemi nyomás befolyásolja a lejátszódó reakciók milyenségét, ezen keresztül pedig az előállított szintézisgáz összetételét és fütőértékét [6].

A plazmatechnológia környezetvédelmi elönyei $[3,6,7,8,9,10]$ :

- Nem igényli a hulladékok előzetes válogatását, tehát azok vegyesen kerülhetnek feladásra, összetételüktől függetlenül.

- A szervetlen hulladékok részben lebomlanak, részben pedig megolvadnak és elüvegesednek. 
- A szerves anyagok teljesen lebomlanak.

- A halogének kémiailag megkötődnek a keletkező üvegben, és onnan nem oldódnak ki.

- A plazma által kibocsátott erős ultraibolya sugárzás meggyorsítja a klór tartalmú szerves vegyületek lebomlását.

- A plazma térben keletkező ultraibolya sugárzás „,bennragad” a plazmaívben, így további gerjesztést idéz elő, amely a hőmérséklet növekedésével jár.

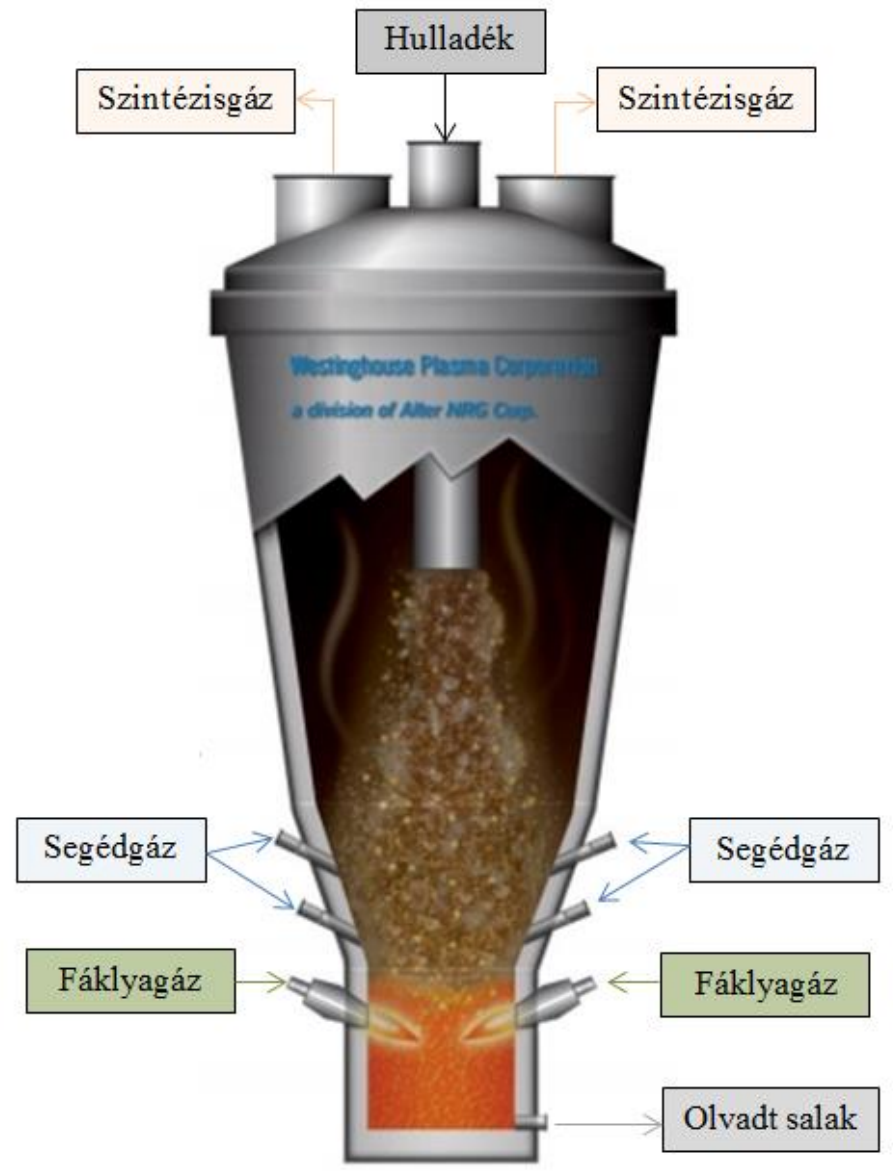

1. ábra. Plazmareaktor felépitése és anyagáramai.

A plazmatechnológia müszaki és gazdasági előnyei $[6,7,9,10,18]$ :

- A plazmatechnológia a nagy hőmérséklet miatt hatékonyan használható minden fajta hulladéktípus (veszélyes, mérgező, halálos) lebontására.

- A folyamat teljesen zárt térben játszódik le, így káros anyagok nem kerülnek a környezetbe.

- A folyamat melléktermékei ártalmatlanok, amelyeket a kohászat valamint az építőipar alapanyagként fel tud használni.

- A hulladékok térfogatának csökkenése 300:1 arányú a hagyományos égetéssel szemben, ahol ez az arány a nagymennyiségü hamu miatt csak 5:1 (szilárd hulladéknál). 
- A plazmatechnológia napi kapacitása a legnagyobb, akár 500 tonna/nap is lehet.

- A plazmatechnológiát alkalmazó gépek számítógép-vezéreltek, csendesek, valamint lehetnek helyhez kötött és mobil kivitelüek.

- A plazmatechnológia alkalmazása során keletkező, a salakba távozó szennyező anyagok, mint például a higany, a kadmium, a kén, a különböző dioxinok valamint a nehézfémek mennyisége jelentősen csökkenthető speciális mosóvíz, száraz gázmosók és szürők alkalmazásával.

Plazmatechnológia hátrányai $[3,6,7,8,9,10]$ :

- A kisebb hőmérsékletü $\left(2.000{ }^{\circ} \mathrm{C}\right.$ alatti) plazma alapú eljárásokban a gáztisztítás összetettebb és komplikáltabb.

- A technológia alkalmazása során keletkező, többnyire erősen szennyezett mosóvizet is komplex módon tisztítani kell.

- Az égetéshez képest nagyobb a lehetősége a nehezen bomló, nem tökéletes égés-termékek képződésének.

\section{Energetikai költség-haszon elemzés}

A költség-haszon elemzés egy olyan döntéstámogató módszer, amely segítséget ad egy termék, technológia, vagy szolgáltatás egységnyi költség befektetésével elérhető haszon becslésére. A módszer a releváns költségek és hasznok beazonosításának kiindulópontjaként szolgál, az alternatív lehetőségek összehasonlításához és értékeléséhez. Vizsgálja az adott projektberuházás során felhasználni kívánt források és az általuk nyerhető bevételeket az összes lehetséges megoldási módozatra vonatkozóan. Ideális esetben a költség-hasznon elemzés bebizonyítja, hogy az egységnyi beruházási költségre jutó haszon nagyobb értékü, ekkor célszerủ az adott beruházást végrehajtani. A legfőbb cél tehát mindig a maximális nettó haszon elérése [11].

A gazdasági haszon bármely olyan jólét-növekedéssel mérhető nyereség, amely a projekt által érintett egyéneknél, vagy program, politika esetén társadalmi szinten jelentkezik. A költséghaszon elemzés elvégzésének kétségtelenül az egyik legnehezebb és legidőigényesebb feladata a hasznok azonosítása és számszerüsítése [11].

A költség-haszon elemzést gyakran egészítik ki kockázatelemzéssel, hogy a reális választási lehetőségek közül a gazdaságilag legstabilabb és emellett a legnagyobb fajlagos haszonnal rendelkező alternatíva kiválasztható legyen. A költség-haszon elemzés elemei a kereslet-kínálati függvény, a nettó jelenérték, a jövedelmezőségi index és a megtérülési ráta [12]. A költségek figyelembe vételekor mind a beruházási, mind a müködési költségeket figyelembe kell venni. A bevételek számba vétele során a társadalmi, környezeti (települési, regionális, nemzeti, közösségi) haszonnal is számolni kell, a pénzügyi, gazdasági hasznok mellett. A profit valamely gazdasági tevékenység során felmerült, számszerüen kifejezett bevételek és ráfordítások különbsége [11].

A költség-haszon elemzés metodikáját tekintve cash-flow szemléletben készül, különös tekintettel a pénz időértékére, mert az egységnyi pénz ma többet ér, mint ugyan az az egységnyi pénz holnap. A cash-flow egy előre meghatározott időszak alatt a pénzforrások képződésének és a felhasználásának a folyamata, állományváltozása. Megmutatja, hogy a vállalkozás a rendelkezésére álló pénzeszközei mely tevékenységi területeken, milyen folyamatok révén keletkeztek és azok felhasználására hol kerül sor. A cash-flow kimutatás egy forgalmi szemléletü kimutatás, amely megmutatja, hogy az egyes tevékenységek milyen hatást gyakorolnak a vállalkozás pénzeszközeire [11]. 
A költség haszon elemzés során először a beruházás megvalósulásának költségeit kell megbecsülni, majd az új projektberuházás üzemeltetési költségeit. A tőkeszükséglet meghatározásánál a megvalósulás során felmerülő forgótőkeigényt is figyelembe kell venni [12].

A kutatómunkám során egyszerüsített, hagyományos értelemben véve nem klasszikus költséghaszon elemzéseket végeztem arra vonatkozóan, hogy a termikus kezelési technológiák során alkalmazott segédgáz lecserélésével milyen gazdasági előnyt lehet elérni. Ennek megfelelően a költséghasznon elemzés az energetikai hatékonyság-vizsgálatokat kiegészítő módszerként alkalmazható, és így az energetikai költség-haszon elemzés kifejezés helytállóbb lehet.

Mivel a plazmatechnológia rendelkezik a legnagyobb beruházási költséggel az alkalmazott 3.000 ${ }^{\circ} \mathrm{C}$ hőmérséklet miatt, ezért ennél a kezelési módszernél célszerü olyan üzemeltetést befolyásoló intézkedéseket, fejlesztéseket megvalósítani, ami tovább növeli a technológia energetikai hatékonyságát, ezen keresztül pedig csökkenti a fajlagos üzemeltetési költségeket.

A költség-haszon elemzés a következő fö lépések sorozata [12]:

1. A projektjavaslatok elvárt eredményeinek megerősítése (tisztázása).

2. Az elemzést meghatározó feltételek, hipotézisek lefektetése.

3. Az elemzési (értékelési) időszak kijelölése.

4. Minden jelentős költség és haszon beazonosítása, realitásának ellenőrzése.

5. Amennyiben lehetséges, pénzben kifejezhető érték rendelése az egyes hasznokhoz és költségekhez (magának a hozzárendelési mechanizmusnak a kiválasztása és alkalmazása).

6. A hasznok és költségek diszkontálása, jelenértékének kiszámítása

7. A kockázatok és bizonytalanság értékelése.

8. A pénzben nem, vagy nehezen mérhető hasznok és költségek hatásainak felmérése.

9. A megfelelő javaslat kidolgozása.

A költség-haszon elemzések három legfontosabb típusa [12]:

- Változatok elemzése, amelynek célja annak alátámasztása, hogy a projekt a megvalósítható alternatívák közül a legjobb.

- A pénzügyi elemzés, amely a kiválasztott müszaki megoldásra vonatkozóan a beruházónál, kedvezményezettnél felmerülő költségeket és bevételeket veszi számba és veti össze, pénzáram (cash-flow) szemléletben. Ennek keretében kell a pénzügyi fenntarthatóságot is vizsgálni.

- A közgazdasági költség-haszon elemzés, amelynek célja a kiválasztott müszaki megoldásra vonatkozóan a társadalmi hasznosság és költségek vizsgálata. Tekintettel arra, hogy ennek a vizsgálatnak a keretében a pénzügyi hasznokat és költségeket kell kiegészíteni vagy felváltani társadalmi költségekkel és hasznokkal, ezért ezt társadalmi-gazdasági elemzésnek is tekinthetjük.

Az energetikai hatékonyság növelésének egyik módszere a segédgáz összetételének módosítása, aminek költség vonzata is létezik. A cél, hogy olyan segédgáz-keveréket találjunk, ami a legkisebb anyagi ráfordítás mellett, a legnagyobb fajlagos energia kihozatalt biztosítja, ezért egy optimumkeresési eljárást kell alkalmazni, ami kvázi pénzügyi költség - energetikai haszon elemzést jelent. Ennek eredményeként előáll az anyagösszetételtől és nedvességtartalomtól függő, minden tekintetben optimális összetételű segédgáz keverék. 
Az energetikai költség-haszon elemzés lényege, hogy az alternatív segédgáz fajlagos energia kihozatalra gyakorolt hatását, valamint a bevétel növekedést és annak bekerülési költségét vizsgáljuk. Egy segédgáz akkor nevezhető költséghatékonynak, ha az általa elért nyereség nagyobb, mint a ráfordított költség. A levegővel történő kezelés esetében ez egyértelműen érvényesül, mert a levegő korlátlan mennyiségben áll a rendelkezésünkre. Legnagyobb problémája, hogy a benne lévő energetikailag inert gázok (nitrogén) nagy mennyisége miatt az elő́llított szintézisgáz fajlagos mennyisége megnő, emiatt kicsi az energiasürüsége. Az energiasürüség növelése a ballasztként viselkedő összetevők leválasztásával megvalósítható, de ennek jelentős költségvonzata ismeretes. Reális megoldásként a levegő lecserélésével, vagy a levegő és egyéb gáz megfelelő arányú keverékének alkalmazásával számolhatunk.

Az energiasűrüség növekedésével a gázkezelő rendszer beruházási és üzemeltetési költségei is csökkenthetők. Az erőmü teljes élettartama alatt előállított energia kihozatalra nézve a segédgáz bekerülési költsége a mérvadó, ezért a számítások során csak ezt vettem figyelembe.

Egy alternatív segédgáz alkalmazása akkor nevezhető gazdaságos megoldásnak, ha a levegő közeghez viszonyított energiatöbbletből származó bevétel nagyobb, mint az alternatív segédgáz bekerülési költsége. Ennek megállapítása érdekében további modellvizsgálatokat végeztem. A modellezés során azt vizsgáltam, hogy a levegő segédgáz lecserélése, illetve szén-dioxiddal, valamint vízgőzzel történő keverése, hogyan változtatja a szintézisgáz kémiai összetételét, valamint milyen mértékben növeli a fajlagos energia kihozatalt. Az elemzések elkészítettem tiszta szén-dioxidra és tiszta vízgőzre vonatkozóan is. Példaként egy átlagos összetételü biomasszára kapott eredményeket mutatom be. Az átlagos fás szárú biomassza moláris képlete: $\mathrm{CH}_{1,25} \mathrm{O}_{0,4}$.

A szén-dioxid nagy bekerülési költsége miatt arra az eredményre jutottam, hogy a szén-dioxid segédgázként történő alkalmazása fás szárú biomassza plazmatechnológiával történő kezelése során nem gazdaságos megoldás. A palackozott, tiszta szén-dioxid átlagosan 280-300 Ft/kg-os ára mellett alkalmazása még levegővel történő keveréssel sem gazdaságos. Ellenben, ha nem élelmiszeripari minőségü, hanem vegyipari szintézisekből származó szén-dioxidot alkalmazunk, a gazdasági mutatók javíthatók. Mivel a metanol gyártás során jelentős mennyiségü szén-dioxid szabadul fel, ezért célszerü egy kombinált rendszert kialakítani. Az így létrejött technológia-együttesben a metanol reakciók során felszabaduló szén-dioxid a plazmatechnológiába segédgázként bevihető.

Másik lehetőség a keletkező szintézisgázban, illetve az erőművi hasznosítást követően felszabaduló, füstgázban található szén-dioxid leválasztása és segédgázként történő visszavezetése a technológiába. Üzemi költségként a leválasztáshoz használt segédanyagok ára és a berendezések energiaigényének költségei jelentkezik, amelyek így befolyásolják a plazmatechnológia gazdaságosságát és müködési hatékonyságát [13].

Alapadatként a 38\%-os nettó villamos hatásfokkal rendelkező gázmotoros energiatermelést tekintettem [14]. A megtermelt villamos energia kötelező átvételi ára 2020-ban a napi csúcs, a völgy és a mélyvölgy időszakok időarányos felosztása alapján átlagosan $31,88 \mathrm{Ft} / \mathrm{kWh}$, a szén-dioxid ára 280 Ft/kg. A 15\%-os nedvességtartalmú fa plazmatechnológiával történő kezelése során, a szén-dioxid segédgázzal elérhető energiasürüség növekedés mértékét, valamint a kiadási és a bevételi oldalt az 1. táblázat tartalmazza. A számításokat a $[15,16]$ irodalmak által ismertetett példák alapján végeztem el. 
1. táblázat. Szén-dioxid segédgáz alkalmazásának energetikai hatása és pénzügyi vonzata plazmatechnológiánál.

\begin{tabular}{|c|c|c|c|c|c|c|c|}
\hline $\begin{array}{c}\text { Levegö } \\
{\left[\mathbf{k g} / \mathbf{k g}_{\mathbf{f a}}\right]}\end{array}$ & $\begin{array}{c}\mathbf{C O}_{\mathbf{2}} \\
{\left[\mathbf{k g} / \mathbf{k g}_{\mathbf{f a}}\right]}\end{array}$ & $\begin{array}{c}\mathbf{C O}_{\mathbf{2}} \\
\text { tartalom }\end{array}$ & $\begin{array}{c}\boldsymbol{e}_{\boldsymbol{k}} \\
{\left[\mathbf{M J} / \mathbf{k g}_{\mathbf{f a}}\right]}\end{array}$ & $\begin{array}{c}\Delta \boldsymbol{e}_{\boldsymbol{a} \boldsymbol{k}} \\
{[-]}\end{array}$ & $\begin{array}{c}\mathbf{K i a d a ́ s} \\
{\left[\mathbf{F t} / \mathbf{k g}_{\mathbf{f a}}\right]}\end{array}$ & $\begin{array}{c}\text { Bevétel } \\
{\left[\mathbf{F t} / \mathbf{k g}_{\mathbf{f a}}\right]}\end{array}$ & $\begin{array}{c}\text { Profit } \\
{\left[\mathbf{F t} / \mathbf{k g}_{\mathbf{f a}}\right]}\end{array}$ \\
\hline 2,8572 & 0,0000 & $0 \%$ & 11,0083 & 1,0000 & 0,00 & 27,30 & 27,30 \\
\hline 2,7143 & 0,1429 & $5 \%$ & 11,5929 & 1,0531 & 40,00 & 28,75 & $-11,25$ \\
\hline 2,5714 & 0,2857 & $10 \%$ & 12,1764 & 1,1061 & 80,00 & 30,19 & $-49,81$ \\
\hline 2,4286 & 0,4286 & $15 \%$ & 12,7614 & 1,1593 & 119,99 & 31,64 & $-88,36$ \\
\hline 2,2857 & 0,5714 & $20 \%$ & 13,3453 & 1,2123 & 160,00 & 33,09 & $-126,91$ \\
\hline
\end{tabular}

Jelölések jelentése:

- $\boldsymbol{e}_{\boldsymbol{k}}$ a fajlagos energiakihozatal,

- $\Delta \boldsymbol{e}_{\boldsymbol{a} \boldsymbol{k}}$ az abszolút összesített energiasürüség-változás.

A szén-dioxid bekerülési költségének változására vonatkozóan érzékenység-vizsgálatot végeztem. Megvizsgáltam, hogy a felhasznált szén-dioxid ára hogyan befolyásolja a költség-haszon görbét, a fedezeti pontot (2. ábra).

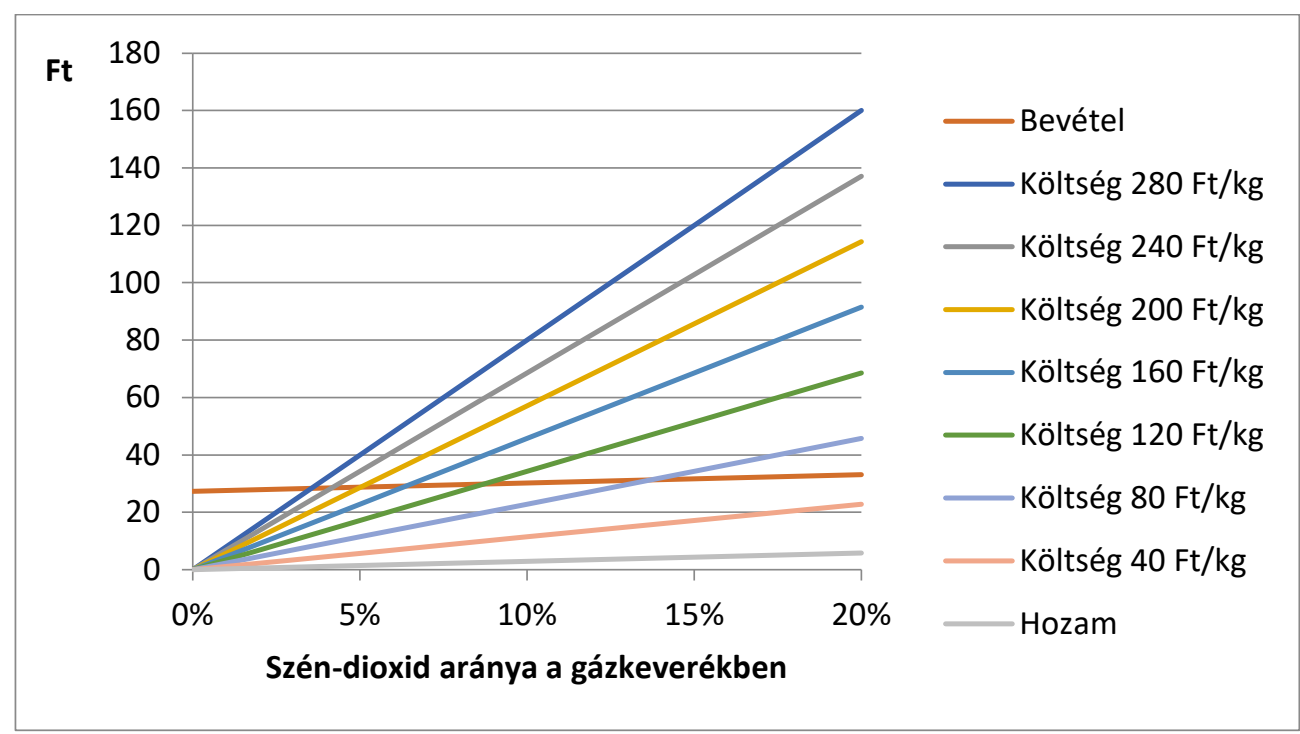

2. ábra. Széndioxid bekerülési költségének hatása a fedezeti pontra.

Megfigyelhető, hogy a széndioxid bekerülési költsége nagyobb meredekségü függvénnyel írható le, mint a bevételi görbe. Amennyiben csökken a szén-dioxid ára, nagyobb keverési arány mellett érjük el a fedezeti pontot. Ennél nagyobb keverési arány mellett a technológia müködtetése veszteséges lesz. A számítások azt eredményezték, hogy csak abban az esetben érhetünk el bevételtöbbletet (hozamot), ha a szén-dioxid előállítási, vagy bekerülési költsége 10,13 Ft/kg értékhatár alatt marad. 
Megvizsgáltam azt az esetet is, amikor a szén-dioxid bekerülési költsége mellett a keverési arány, az erőgép hatásfoka, valamint a villamos energia kötelező átvételi ára is változik. Mindezek figyelembe vételével sikerült felírnom egy összefüggést a legkisebb négyzetek módszerének alkalmazásával (1. összefüggés), amely megmutatja, hogy ha változik az előbb említett paraméterek egyike, akkor hogyan alakul a bevételi oldal. A függvény átrendezésével megadható az a keverési arány, amelynél a technológia bevételi és kiadási oldala megegyezik (különbségük nullával egyenlö), azaz a fedezeti pont.

Mindezek alapján a haszon:

$$
H=0,5352 \cdot \sqrt[2]{A_{\mathrm{CO}_{2}}}+0,01519 \cdot \eta_{e g v}{ }^{2}-0,1428 \cdot K T G_{\mathrm{CO}_{2}}+0,01519 \cdot B_{e}{ }^{2}
$$

függvénnyel írható le, ahol:

- $H$ a haszon,

- $A_{\mathrm{CO} 2}$ a szén-dioxid keverési aránya,

- $\eta_{e g v}$ az erőgép nettó villamos hatásfoka,

- $\quad K T G_{\mathrm{CO} 2}$ a szén-dioxid bekerülési költsége és

- $B_{e}$ a villamos energia átvételi ára.

A modellezések során a vízgőz alkalmazása pozitív eredményt hozott. A vízgőz előállításának nincs közvetlen költsége, mert a szintézisgáz hütéséből származó hő közvetlenül alkalmazható vízgőz előállítására. Mind önálló segédgázként, mind a levegővel keverten történő alkalmazása egyaránt növeli a fajlagos energia kihozatalt [17]. Ebből következik, hogy a vízgőz alkalmazása nagyobb haszonnal jár, mint költséggel. Alkalmazhatósági korlátját a kezelésre kerülő alapanyag nedvességtartalma jelenti. A nedvességtartalom növekedésével arányosan csökken az energia sürüség növekedés mértéke. 40\%-os nedvességtartalommal rendelkező alapanyagoknál már nem érhető el energia kihozatal növekedés. Az elemzés alapadatai az előzőekben elmondottakkal megegyező. Az így kapott eredményeket a 2. táblázat tartalmazza.

2. táblázat. Vizgöz segédgáz alkalmazásának energetikai hatása és pénzügyi vonzata plazmagázositásnál

\begin{tabular}{|c|c|c|c|c|c|c|c|}
\hline $\begin{array}{c}\text { Levegö } \\
{\left[\mathbf{k g} / \mathbf{k g}_{\mathbf{f a}}\right]}\end{array}$ & $\begin{array}{c}\text { Göz } \\
{\left[\mathbf{k g} / \mathbf{k g} \mathbf{f a}_{\mathbf{f}}\right]}\end{array}$ & $\begin{array}{c}\text { Göz- } \\
\text { tartalom }\end{array}$ & $\begin{array}{c}\boldsymbol{e}_{\boldsymbol{k}} \\
{\left[\mathbf{M J} / \mathbf{k g}_{\mathbf{f a}}\right]}\end{array}$ & $\begin{array}{c}\Delta \boldsymbol{e}_{\boldsymbol{a k}} \\
{[-]}\end{array}$ & $\begin{array}{c}\text { Kiadás } \\
{\left[\mathbf{F t} / \mathbf{k g}_{\mathbf{f a}}\right]}\end{array}$ & $\begin{array}{c}\text { Bevétel } \\
{\left[\mathbf{F t} / \mathbf{k g}_{\mathbf{f a}}\right]}\end{array}$ & $\begin{array}{c}\text { Profit } \\
{\left[\mathbf{F t} / \mathbf{k g}_{\mathbf{f a}}\right]}\end{array}$ \\
\hline 2,8572 & 0 & $0 \%$ & 11,0083 & 1,0000 & 0,00 & 27,2957 & 27,2957 \\
\hline 2,7143 & 0,1429 & $5 \%$ & 11,4693 & 1,0419 & 0,00 & 28,4387 & 28,4387 \\
\hline 2,5714 & 0,2857 & $10 \%$ & 11,9383 & 1,0845 & 0,00 & 29,6017 & 29,6017 \\
\hline 2,4286 & 0,4286 & $15 \%$ & 12,4108 & 1,1274 & 0,00 & 30,7734 & 30,7734 \\
\hline 2,2857 & 0,5714 & $20 \%$ & 12,8886 & 1,1708 & 0,00 & 31,9579 & 31,9579 \\
\hline
\end{tabular}

A nagyobb $\mathrm{H} / \mathrm{C}$ és $\mathrm{O} / \mathrm{C}$ aránnyal rendelkező fás szárú biomasszák esetében az energia sürüség növekedés mértéke az aránypárok növekedésével arányosan csökkenő tendenciát mutat. Ezekben az esetekben a segédgáz cseréjével kisebb energia sürüség növekedés, és profitnövekedés érhető el. 


\section{4. Összefoglalás}

Egyszerüsített energetikai költség-haszon elemzést végeztem a plazmatechnológiánál alkalmazott különböző gázosító közegek fajlagos energiakihozatalra gyakorolt hatásának függvényében. A palackozott, tiszta szén-dioxid nagy bekerülési költsége miatt, arra az eredményre jutottam, hogy annak segédgázként történő alkalmazása nem gazdaságos a fás szárú biomassza plazmatechnológiával történő kezelése során. Felírtam egy összefüggést a gazdasági haszonra a szén-dioxid bekerülési költségének és keverési arányának, a villamos energia átvételi árának, valamint az erőgép hatásfokának függvényében. A vízgőz előállításának nincs közvetlen költsége, mert a szintézisgáz hütéséből származó hő közvetlenül alkalmazható. A vízgőz, mind önálló segédgázként, mind levegővel keverten történő alkalmazása egyaránt növeli a fajlagos energiakihozatalt. A vízgőz alkalmazása $40 \%$-os nedvességtartalmú alapanyagig nagyobb haszonnal jár, mint költséggel [19].

\section{Köszönetnyilvánítás}

A cikkben ismertetett kutató munka az EFOP-3.6.1-16-2016-00011 jelü „Fiatalodó és Megújuló Egyetem - Innovatív Tudásváros - a Miskolci Egyetem intelligens szakosodást szolgáló intézményi fejlesztése" projekt részeként - a Széchenyi 2020 keretében - az Európai Unió támogatásával, az Európai Szociális Alap társfinanszírozásával valósul meg.

\section{Irodalom}

[1] Thompson, W.: Bevezetés a plazma fizikába. Budapest, 1970.

[2] Murphy, J. D., McKeogh, E.: Technical, economic and environmental analysis of energy production from municipal solid waste. Renewable Energy 29. 2004. pp. 1043-1057 https://doi.org/10.1016/j.renene.2003.12.002

[3] Mountouris, A., Voutsas, E., Tassios, D.: Plasma gasification of sewage sludge: Process development and energy optimization. Energy Conversion and Management 49. 2008. pp. 2264-2271. https://doi.org/10.1016/j.enconman.2008.01.025

[4] Örvös, M.: Ártalmatlanítás termikus eljárásokkal. Oktatási segédlet BME, 2011. p. 31.

[5] Huang, H., Tang, L.: Treatment of organic waste using thermal plasma pyrolysis technology. Energy Conversion and Management 48. 2007. pp. 1331-1337. https://doi.org/10.1016/j.enconman.2006.08.013

[6] Klinghoffer, N., B., Castaldi, M., J.: Waste to energy conversion technology. Woodhead Publishing, Philadelphia, USA, 2013. p. 234. https://doi.org/10.1533/9780857096364

[7] Szuhi, A.: Új termikus technológiák és hagyományos hulladékégetők. Környezetvédelmi és Vízügyi Minisztérium 2009. p. 36.

[8] Szuhi, A.: Az új termikus technológiák környezeti hatásai (pirolízis, elgázosítás és plazma technológia). Humusz Szövetség és Vidékfejlesztési Minisztérium 2013. p. 14.

[9] Szépvölgyi, J.: Anyagok átalakítása magas hőmérsékletủ plazmákban. Müszerügyi és Méréstechnikai Közlemények. 2000. (36. évf.) 65. sz. p. 4.

[10] Lee, S., Speight, J., G., Loyalka, S., K.: Handbook of alternative fuel technologies. Taylor \& Francis, 2015. p. 686. https://doi.org/10.1201/b17157 
[11] Kóródi, M. (szerkesztő): Turizmus kutatások módszertana. Pécsi Tudományegyetem. 2011. p. 200.

[12] A közigazgatási Informatikai Bizottság 29. számú ajánlása: Az elektronikus közigazgatási projektek költség-haszon elemzéséröl. 2009. p. 69.

[13] Kapros, T.: Erőmüi CCS technológiák költségei, a piacképességet fokozó intézkedések. hulladékOnline, elektronikus folyóirat. 3. évf. 2012. 2. sz. p. 16.

[14] Huang, H., Tang, L.: Treatment of organic waste using thermal plasma pyrolysis technology. Energy Conversion and Management 48. 2007. pp. 1331-1337. https://doi.org/10.1016/j.enconman.2006.08.013

[15] Horváth, Zs.: Képletgyüjtemény. Nemzeti Tankönyvkiadó Budapest, 2011.

[16] Bozsik, S.: Pénzügyi számítások. Oktatási segédlet. Miskolci Egyetem, 2009. p. 175.

[17] Schuster, G., Löffer, G., Weigel, K., Hofbauer, H.: Biomass steam gasification - an extensive parametric modeling study. Bioresource Technology. Vol. 77. 2001. pp. 71-79. https://doi.org/10.1016/S0960-8524(00)00115-2

[18] Young, G., C.: Municipal solid waste to energy conversion process, economic, technical, and renewable comparisons. John Will \& Sons, Inc., New Jersey, USA, 2010. p. 379. https://doi.org/10.1002/9780470608616

[19] Bodnár, I.: Hulladékok energetikai célú hasznosításának vizsgálata energiahatékonyság, költséghaszon és életciklus-elemzési módszerekkel. Ph.D. értekezés, Miskolci Egyetem, 2016. p. 161. 